\title{
A New Ruthenium Sensitizer Containing Benzo $[1,9]$ quinolizino(acridin-2-yl)vinyl-2,2'-bipyridine Ligand for Effective Nanocrystalline Dye-Sensitized Solar Cells
}

\author{
Jeum-Jong Kim, ${ }^{1}$ Jeonghun Yoon, ${ }^{1}$ Eun Jung Kim, ${ }^{2}$ Bo Ram Kim, ${ }^{2}$ Yong-Jin Yoon, ${ }^{2}$ \\ and Mangu Kang ${ }^{1}$ \\ ${ }^{1}$ Advanced Solar Technology Research Department, Electronics and Telecommunications Research Institute, \\ Daejeon 305-700, Republic of Korea \\ ${ }^{2}$ Department of Chemistry and Research Institute of Natural Science, Gyeongsang National University, \\ Chinju 660701, Republic of Korea
}

Correspondence should be addressed to Mangu Kang, 10009kang@etri.re.kr

Received 10 June 2011; Accepted 13 December 2011

Academic Editor: Peter Rupnowski

Copyright ( 2012 Jeum-Jong Kim et al. This is an open access article distributed under the Creative Commons Attribution License, which permits unrestricted use, distribution, and reproduction in any medium, provided the original work is properly cited.

Novel ruthenium bipyridyl sensitizer incorporating conjugated benzo[1,9]quinolizino-(acridin-2-yl)vinyl-2,2'-bipyridine ligand [JJ-12] has been synthesized and demonstrated as efficient sensitizer in dye-sensitized solar cells. A mesoporous titania film stained with JJ-12 exhibits a remarkable incident monochromatic photon-to-current conversion efficiency of $82 \%$. Under standard AM 1.5 sunlight, the solar cell using a liquid-based electrolyte consisting of 0.6 M 1,2-dimethyl-3-propylimidazolium iodide (DMPII), $0.05 \mathrm{M} \mathrm{I}_{2}, 0.1 \mathrm{M} \mathrm{LiI}$, and $0.5 \mathrm{M}$ tert-butylpyridine in acetonitrile exhibits a short-circuit photocurrent density of $16.47 \mathrm{~mA} / \mathrm{cm}^{2}$, an open-circuit voltage of $0.71 \mathrm{~V}$, and a fill factor of 0.71 , corresponding to an overall conversion efficiency of $8.34 \%$.

\section{Introduction}

Dye-sensitized solar cells (DSSCs) have been extensively studied as a novel sunlight-to-electricity conversion system [1-5]. The working principle of the dye-sensitized solar cell is the following. Upon photoexcitation, the dye molecules inject an electron into the conduction band of $\mathrm{TiO}_{2}$, leaving the dye in its oxidized state $(\mathrm{D}+$, also referred to as dye cation). The dye is restored to its ground state by electron transfer from the redox pair. The regeneration of the sensitizer by iodide intercepts the recombination of the conduction band electron with the oxidized dye. The $\mathrm{I}_{3}{ }^{-}$ions formed by oxidation of $\mathrm{I}^{-}$diffuse to the cathode where the regenerative cycle is completed by electron transfer to reduce $\mathrm{I}_{3}{ }^{-}$to $\mathrm{I}^{-}$. DSSCs consist of a dye-sensitized $\mathrm{TiO}_{2}$ electrode, a Pt-sputtered counter electrode, and a redox couple. In these cells, the sensitizer is one of the key components for high-power conversion efficiencies. Polypyridyl ruthenium sensitizers such as cis-dithiocyanato-bis (4,4'-dicarboxy-2,2' bipyridine)ruthenium (II) (N719) have shown to be excellent dyes in DSSCs, and their photoconversion efficiency is more than $10 \%$ under air mass 1.5 sunlight [6]. The main drawback of this sensitizer is the lack of absorption in the red region of the visible spectrum. An important goal on ruthenium dyes has been the development of new ruthenium dyes having a wide and red-shifted MLCT band [7-9]. Numerous attempts have been made to molecularly engineer ruthenium sensitizers to broaden the absorption band and increase the molar absorption coefficient. One of the successful approaches is to replace one of the 4,4'dicarboxylic acid-2,2' -bipyridine (dcbpy) anchoring ligands in N3 with a highly conjugated ancillary ligand. Several groups have successfully developed efficient ruthenium sensitizers by introducing extended conjugation units on the bipyridyl ligand such as thiophene [10-14] and alkoxybenzene [15-17] derivatives. Another approach is to synthesize 


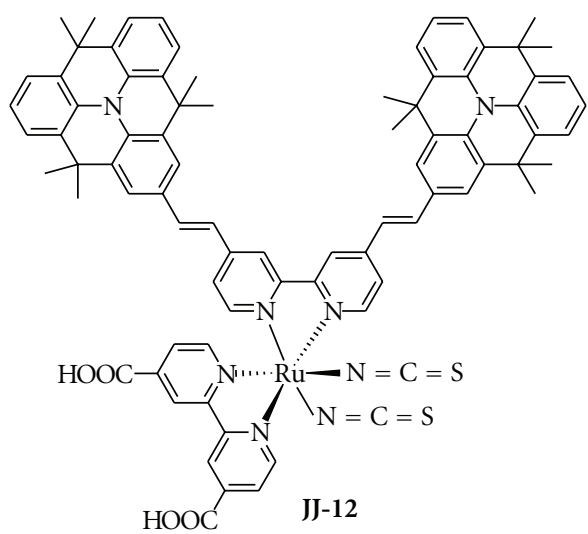

Figure 1: Molecular structure of JJ-12.

efficient ruthenium sensitizers through a systematic tuning of the LUMO and HOMO energy levels of the ruthenium polypyridyl complexes by introducing a ligand with a lowlying $\pi^{*}$ molecular orbital or by destabilizing the metal $t_{2 \mathrm{~g}}$ orbital with a strong donor ligand [18]. Thus, the systematic designs of efficient ruthenium sensitizers to enhance the absorption coefficient and red shift the MLCT band by increasing the conjugation length of the ancillary ligands such as a styryl-substituted bipyridine and using strong $\sigma$ donating power of the amine are well documented strategies. As even small structural modifications of sensitizers result in significant changes in redox energies and the threshold wavelength, the ruthenium sensitizer, JJ-12, is molecularly engineered in a way to have a red-shift and high absorption coefficient of MLCT band. Here, we report the synthesis of a novel ruthenium sensitizer containing benzo[1,9]quinolizino(acridin-2-yl)vinyl-2,2' -bipyridine and its excellent photovoltaic performances in DSSCs (Figure 1).

\section{Experimental Section}

2.1. NMR Spectra, UV-Vis Spectra, and Emission Spectra Measurement. All of the reactions were carried out under an argon atmosphere. ${ }^{1} \mathrm{H}$ and ${ }^{13} \mathrm{C}$ NMR spectra were recorded on a Varian Mercury 300 spectrometer. UV-vis spectra were recorded in a $1 \mathrm{~cm}$ path length quartz cell on a Cary 5 spectrophotometer. Emission spectra were recorded on a Spex Fluorolog 112 using a $90^{\circ}$ optical geometry. The emitted light was detected with a Hamamatsu R928 photomultiplier operated in single-photon counting mode.

\subsection{Electrochemical Impedance Spectra (EIS) and I-V Curve} Spectra Measurement. Electrochemical impedance spectra (EIS) of DSSCs were measured with an impedance analyzer (VersaSTAT 3, AMETEK) connected to a potentiostat under illumination conditions at room temperature. The spectra were scanned in a frequency range from $10^{-1} \mathrm{~Hz}$ to $10^{5} \mathrm{~Hz}$ and AC amplitude $10 \mathrm{mV}$ at room temperature.

Photoelectrochemical data were measured using a $1000 \mathrm{~W}$ xenon light source (Oriel, 91193) that was focused to give $1000 \mathrm{~W} / \mathrm{m}^{2}$, the equivalent of one sun at air mass
(AM) 1.5, at the surface of the test cell. The light intensity was adjusted with an Si solar cell that was doubled-checked with an NREL-calibrated Si solar cell (PV Measurement Inc.). The applied potential and measured cell current were measured using a Keithley model 2400 digital source meter. The current-voltage characteristics of the cell under these conditions were determined by biasing the cell externally and measuring the generated photocurrent. This process was fully automated using WaveMetrics software.

2.3. Dye-Sensitized Solar Cell Fabrication. Fluorine-doped tin oxide (FTO) glass plates (Pilkington TEC Glass-TEC 8 , Solar $2.3 \mathrm{~mm}$ thickness) were cleaned in a detergent solution using an ultrasonic bath for $30 \mathrm{~min}$ and then rinsed with water and ethanol. Then, the plates were immersed in $40 \mathrm{mM} \mathrm{TiCl}_{4}$ (aqueous) at $70^{\circ} \mathrm{C}$ for $30 \mathrm{~min}$ and washed with water and ethanol. A transparent nanocrystalline layer was prepared on the FTO glass plates by using a doctor blade printing $\mathrm{TiO}_{2}$ paste (Solaronix, Ti-Nanoxide T/SP), which was then dried for $2 \mathrm{~h}$ at $25^{\circ} \mathrm{C}$. The $\mathrm{TiO}_{2}$ electrodes were gradually heated under an air flow at $325^{\circ} \mathrm{C}$ for $5 \mathrm{~min}$, at $375^{\circ} \mathrm{C}$ for $5 \mathrm{~min}$, at $450^{\circ} \mathrm{C}$ for $15 \mathrm{~min}$, and at $500^{\circ} \mathrm{C}$ for $15 \mathrm{~min}$. The thickness of the transparent layer was measured by using an Alpha-Step 250 surface profilometer (Tencor Instruments, San Jose, CA, USA). A Paste containing $400 \mathrm{~nm}$ sized anatase particles (CCIC. PST-400C) was deposited by means of doctor blade printing to obtain the scattering layer, and then dried and heated under same condition which was applied for $\mathrm{TiO}_{2}$ (Solaronix, Ti-Nanoxide T/SP) paste described above. The resulting film was composed of a $10 \mu \mathrm{m}$ thick transparent layer and a $4 \mu \mathrm{m}$ thick scattering layer. The $\mathrm{TiO}_{2}$ electrodes were treated again with $\mathrm{TiCl}_{4}$ at $70^{\circ} \mathrm{C}$ for $30 \mathrm{~min}$ and sintered at $500^{\circ} \mathrm{C}$ for $30 \mathrm{~min}$. Then, they were immersed in $\mathbf{J J - 1 2}(0.3 \mathrm{mM}$ in ethanol) solutions and kept at room temperature for $24 \mathrm{~h}$. FTO plates for the counter electrodes were cleaned in an ultrasonic bath in $\mathrm{H}_{2} \mathrm{O}$, Acetone, and $0.1 \mathrm{M}$ aqueous $\mathrm{HCl}$, subsequently. The counter electrodes were prepared by placing a drop of an $\mathrm{H}_{2} \mathrm{PtCl}_{6}$ solution ( $2 \mathrm{mg} \mathrm{Pt}$ in $1 \mathrm{~mL}$ ethanol) on an FTO plate and heating it (at $400^{\circ} \mathrm{C}$ ) for $15 \mathrm{~min}$. The dye adsorbed $\mathrm{TiO}_{2}$ electrodes, and the Pt counter electrodes were assembled into a sealed sandwich-type cell by heating at $80^{\circ} \mathrm{C}$ using a hot-melt ionomer film (Surlyn) as a spacer between the electrodes. A drop of the electrolyte consisting of $0.6 \mathrm{M} \mathrm{1,2-}$ dimethyl-3-propylimidazolium iodide (DMPII), 0.05 $\mathrm{M} \mathrm{I}_{2}$, $0.1 \mathrm{M}$ LiI, and $0.5 \mathrm{M}$ tert-butylpyridine in acetonitrile was placed in the drilled hole of the counter electrode and was driven into the cell via vacuum backfilling. Finally, the hole was sealed using additional surlyn and a cover glass $(0.1 \mathrm{~mm}$ thickness).

2.4. Typical Synthesis Procedures and Analytical Data. 4,4'bis((E)-2-(4,4,8,8,12,12-hexamethyl-8,12-dihydro-4Hbenzo[1,9] quinolizino[3,4,5,6,7-defg] acridin-2-yl)vinyl)2,2' -bipyridine (7): 4,4,8,8,12,12-hexamethyl-8,12-dihydro4H-benzo[1,9] quinolizino[3,4,5,6,7-defg] acridine-2-carbaldehyde (130 mg, $0.33 \mathrm{mmol})$, tetraethyl[2,2' -bipyridine]-4, $4^{\prime}$-diylbis(methylene) bis(phosphonate) $(80 \mathrm{mg}, 0.17 \mathrm{mmol})$ 
and potassium tert-butoxide (55 $\mathrm{mg}, 0.50 \mathrm{mmol}$ ) were dissolved in tetrahydrofuran $(50 \mathrm{~mL})$, and the mixture was stirred for $0.5 \mathrm{~h}$. After the solvent was removed under reduced pressure, $\mathrm{H}_{2} \mathrm{O}(50 \mathrm{~mL})$ and methylene chloride $(50 \mathrm{~mL})$ were added. The organic layer was separated and dried in $\mathrm{MgSO}_{4}$. The solvent was removed under reduced pressure. The pure product 7 was obtained by column chromatography on silica gel (methylene chloride:hexane $\left.=1: 1, R_{f}=0.3\right)$. Yield: $90 \% .{ }^{1} \mathrm{H}$ NMR $\left(\mathrm{CDCl}_{3}\right): 8.73(\mathrm{~d}$, $2 \mathrm{H}, J=5.1 \mathrm{~Hz}), 8.65(\mathrm{~s}, 2 \mathrm{H}), 7.63(\mathrm{~s}, 4 \mathrm{H}), 7.57(\mathrm{~d}, 2 \mathrm{H}$, $J=16.2 \mathrm{~Hz}), 7.44(\mathrm{~m}, 12 \mathrm{H}), 7.18(\mathrm{~m}, 4 \mathrm{H}), 1.71(\mathrm{~s}, 24 \mathrm{H})$, 1.67 (s, $12 \mathrm{H}) .{ }^{13} \mathrm{C} \mathrm{NMR}\left(\mathrm{CDCl}_{3}\right): 156.5,149.5,146.3,133.4$, $132.8,131.5,130.6,130.2,130.1,129.9,123.9,123.5,123.3$, 122.4, 120.9, 118.1, 35.6, 33.0. Anal. calcd. for $\mathrm{C}_{68} \mathrm{H}_{62} \mathrm{~N}_{4}$ : C, 87.33; H, 6.68. Found: C, 87.30; H, 6.71.

JJ-12 Complex. A mixture 4,4'-bis((E)-2- $(4,4,8,8,12,12-$ hexamethyl-8,12-dihydro-4H-benzo[1,9] quinolizino[3,4,5,6,7-defg] acridin-2-yl)vinyl)-2,2' -bipyridine (130 mg, 0.14 $\mathrm{mmol}$ ) and a dichloro( $p$-cymene)ruthenium (II) dimer (43 mg, $0.07 \mathrm{mmol})$ in argon-degassed DMF $(15 \mathrm{~mL})$ was stirred at $70^{\circ} \mathrm{C}$ for $4 \mathrm{~h}$ under reduced light. Subsequently, $4,4^{\prime}$-dicarboxylic-2,2' -bipyridine ( $34 \mathrm{mg}, 0.14 \mathrm{mmol}$ ) was added into the flask, and the reaction mixture was stirred at $160^{\circ} \mathrm{C}$ for $4 \mathrm{~h}$. At last, an excess of $\mathrm{NH}_{4} \mathrm{NCS}(105 \mathrm{mg}$, $1.40 \mathrm{mmol}$ ) was added to the resulting dark solution, and the reaction continued for another $4 \mathrm{~h}$ at $140^{\circ} \mathrm{C}$. Then the reaction mixture was cooled down to room temperature, and the solvent was removed under vacuum. Water was added to get the precipitate. The precipitate was filtered out, washed with water, and dried under vacuum. The resulting solid was dissolved in methanol containing 2,2 equivalent of tetrabutylammonium hydroxide to confer solubility by deprotonating the carboxylic group and purified on a Sephadex LH-20 column with methanol as eluent. The collected main band was concentrated, and the solution $\mathrm{pH}$ was lowered to 5.1 using $0.02 \mathrm{M}$ nitric acid. The precipitate was collected on a sintered glass crucible by suction filtration and dried in air. Yield: $60 \% .{ }^{1} \mathrm{H}$ NMR $\left(\mathrm{CD}_{3} \mathrm{OD}\right)$ : 9.35-8.90 (m, 6H), 8.23 (s, $1 \mathrm{H}), 8.08-7.18(\mathrm{~m}, 24 \mathrm{H}), 6.86(\mathrm{~s}, 1 \mathrm{H}), 1.61(\mathrm{~m}, 24 \mathrm{H}), 1.33$ $(\mathrm{m}, 12 \mathrm{H}), 0.87(\mathrm{~m}, 9 \mathrm{H})$. Anal. calcd. for $\mathrm{C}_{82} \mathrm{H}_{70} \mathrm{~N}_{8} \mathrm{O}_{4} \mathrm{RuS}_{2}$ : C, 70.52; H, 5.05. Found: C, 70.63; H, 5.01

\section{Results and Discussion}

The synthetic route for the preparation of JJ-12 is depicted in Scheme 1. First, trimethyl $2,2^{\prime}, 2^{\prime \prime}$-nitrilotribenzoate 3 was prepared by the Ullmann coupling reaction [19] of methyl 2-aminobenzoate $\mathbf{1}$ and methyl 2-iodobenzoate $\mathbf{2}$ and compound 6 was synthesized through methylation, cyclization and formylation from compound 3. 2-Bromo4,4' -bis((E)-2-(4,4,8,8,12,12-hexamethyl-8,12-dihydro-4Hbenzo[1,9]quinolizino[3,4,5,6,7-defg]acridin-2-yl)vinyl)-2, $2^{\prime}$-bipyridine 7 was prepared from the reaction of 4,4 , 8,8,12,12-hexamethyl-8,12-dihydro-4H-benzo[1,9]quinolizino[3,4,5,6,7-defg] acridine-2-carbaldehyde 6 and tetraethyl[2,2'-bipyridine]-4,4' -diylbis(methylene))bis(phosphonate) using the Horner-Emmons-Wadsworth reaction [20].

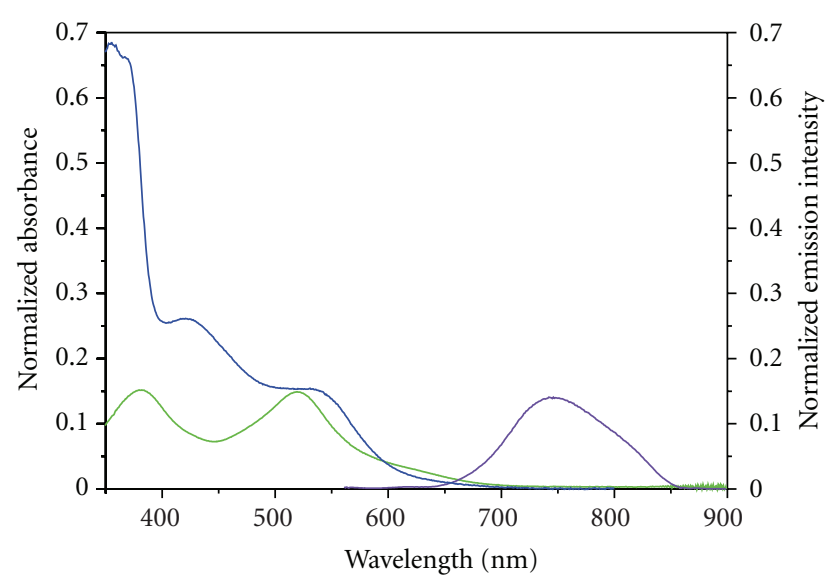

(a)

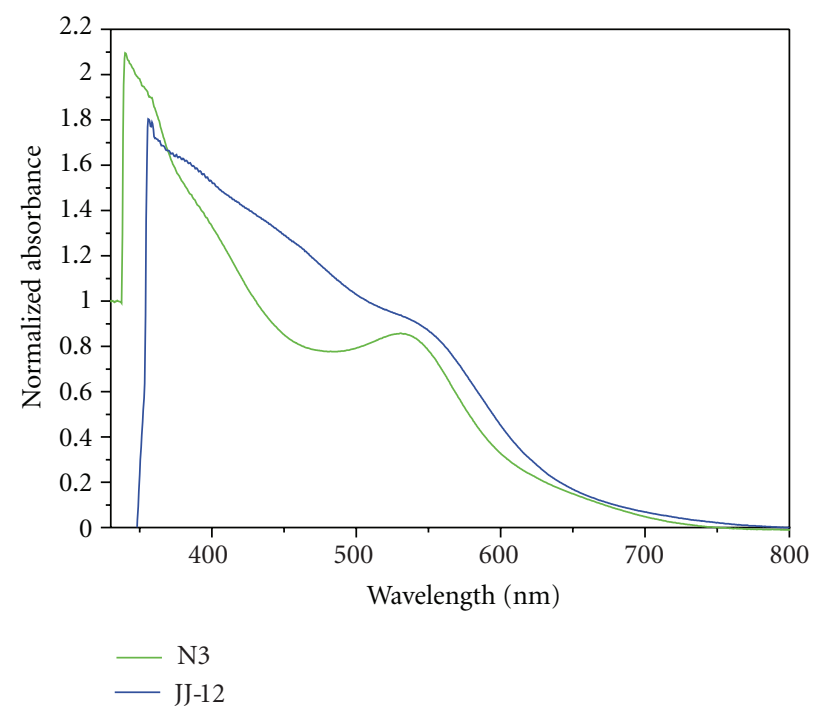

(b)

FIgure 2: Absorption and emission spectra (a) of JJ-12 (blue line) and N3 (green line) in EtOH, and absorption spectra (b) of JJ-12 (blue line) and $\mathbf{N} 3$ (green line) adsorbed on $\mathrm{TiO}_{2}$ film.

The one-pot synthetic procedure developed for heteroleptic polypyridyl ruthenium sensitizers was adapted for the preparation of new JJ-12 [21, 22]. The analytical and spectroscopic data of novel sensitizer are consistent with the formulated structure.

Figure 2 shows the ultraviolet-visible spectra of JJ-12, together with the $\mathbf{N} 3$ absorption spectrum as a reference. The polypyridyl complexes of JJ-12 show very broad and intense absorption peaks throughout the whole absorption region. The UV-vis spectrum of JJ-12 displays two absorption bands at 420 and $531 \mathrm{~nm}$ in the visible region, which are characteristic of the metal-to-ligand charge transfer (MLCT) bands $[23,24]$. The low-energy MLCT band of JJ-12 at $531 \mathrm{~nm}$ is $11 \mathrm{~nm}$ red shifted relative to that of N3. The red shift of JJ-12 sensitizer is attributable to the increase of $\pi$-conjugation in an ancillary ligand and donor ability of 

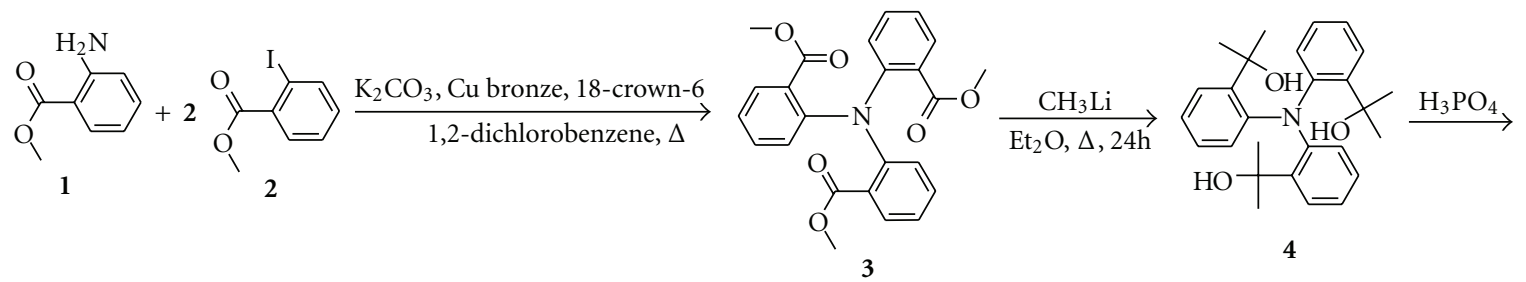

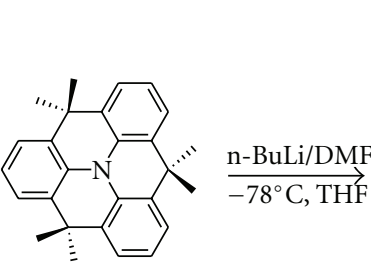

5

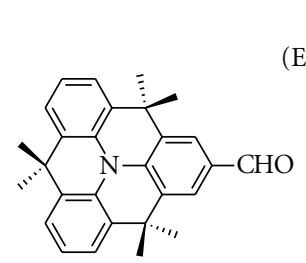

6

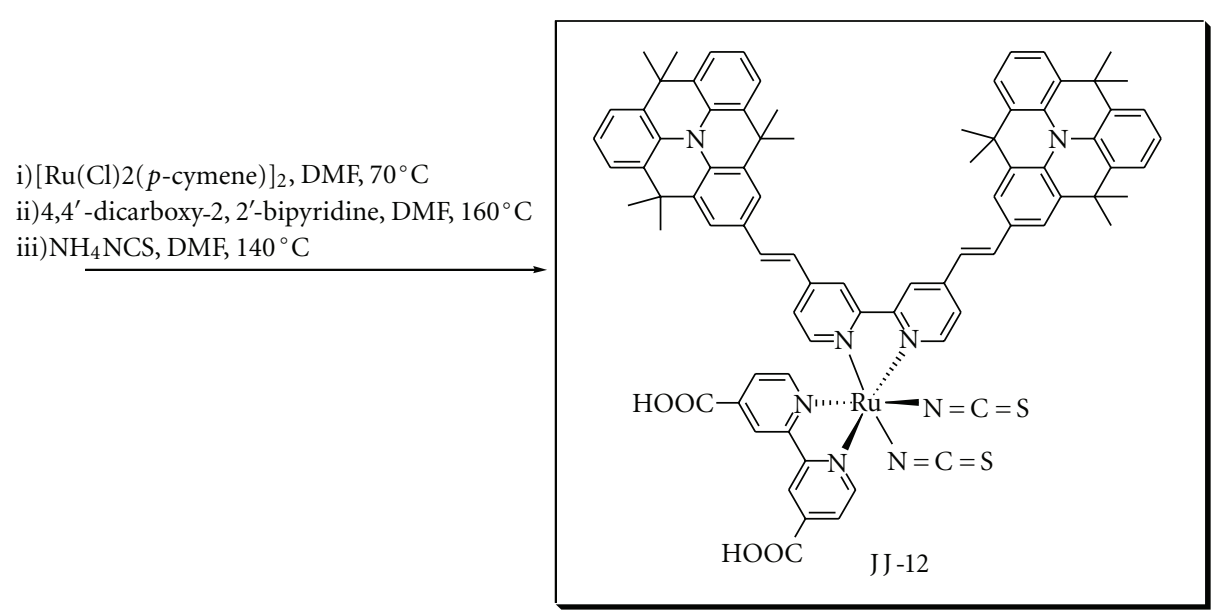

SCHEme 1: Schematic diagram for the synthesis of sensitizers JJ-12.

benzo[1,9] quinolizinoacridine. The low-energy MLCT band at $531 \mathrm{~nm}$ of JJ-12 exhibits a molar extinction coefficient of $15.4 \times 10^{3} \mathrm{M}^{-1} \mathrm{~cm}^{-1}$, which is higher than that of the $\mathrm{N} 3$ dye $\left(14.4 \times 10^{3} \mathrm{M}^{-1} \mathrm{~cm}^{-1}\right)$. Adsorption of JJ-12 onto a $\mathrm{TiO}_{2}$ electrode was observed to broaden the absorption band and to red shift the absorption threshold up to $770 \mathrm{~nm}$, ensuring a good light-harvesting efficiency (Figure 2(b)). Such broadening and red shift have been observed in many ruthenium sensitizers on $\mathrm{TiO}_{2}$ electrodes $[25,26]$.

We also observed that the JJ-12 exhibited strong luminescence maxima at 740-755 $\mathrm{nm}$ when they were excited with their MLCT absorption bands at $298 \mathrm{~K}$ in an air-equilibrated ethanol solution.

The electrochemical properties of the novel sensitizer JJ12 were studied by cyclic voltammetry in $\mathrm{CH}_{3} \mathrm{CN}$ with $0.1 \mathrm{M}$ tetrabutylammonium hexafluorophosphate using $\mathrm{TiO}_{2}$ film with adsorbed dyes as the working electrode. The oxidation potential of JJ-12 adsorbed on $\mathrm{TiO}_{2}$ film shows a quasireversible couple at $0.92 \mathrm{~V}$ versus NHE (Table 1 ). The value may be compared to $1.12 \mathrm{~V}$ versus NHE measured for N3. The $0.20 \mathrm{~V}$ cathodic shift of the JJ-12 oxidation potential compared to that of $\mathbf{N} 3$ is attributable to the influence of the electron-rich fused triphenylamine donor ring. The oxidation potential of JJ-12 sensitizer is energetically favorable for iodide oxidation [27]. The reduction potentials of JJ12 dye calculated from the oxidation potentials and the $E_{0-0}$ determined from the intersection of absorption and emission spectra are $-0.96 \mathrm{~V}$ for $\mathbf{J J - 1 2}$ versus NHE [28]. The value is much more negative than the conduction band level of $\mathrm{TiO}_{2}$ at approximately $-0.5 \mathrm{~V}$ versus NHE, ensuring the thermodynamic driving force for charge injection $[29,30]$.

Figure 3 shows the incident monochromatic photonto-current conversion efficiency (IPCE) using 0.6 M 1,2dimethyl-3-propylimidazolium iodide (DMPII), 0.05 $\mathrm{M} \mathrm{I}_{2}$, $0.1 \mathrm{M}$ LiI, and $0.5 \mathrm{M}$ tert-butylpyridine in acetonitrile. The cell was fabricated using a double layer of $10 \mu \mathrm{m}$ thick $\mathrm{TiO}_{2}$ (20 nm nanoparticles) and $4 \mu \mathrm{m}$ thick scattering $\mathrm{TiO}_{2}$ (400 nm nanoparticles). The incident photon-to-current conversion efficiency (IPCE) of JJ-12 exceeds 70\% in a broad spectral range from 440 to $630 \mathrm{~nm}$, reaching a maximum $82 \%$ at $520 \mathrm{~nm}$. The band tails off toward $800 \mathrm{~nm}$, contributing to the broad spectral light harvesting that is characteristic of polypyridyl ruthenium dyes [31-33]. For reference, N3 dye affords a maximum IPCE of $75 \%$ at $520 \mathrm{~nm}$ under the 
TABLE 1: Optical, oxidation, and DSSC performance parameters of dyes.

\begin{tabular}{|c|c|c|c|c|c|c|c|c|}
\hline Dye & $\lambda_{\mathrm{abs}}{ }^{\mathrm{a}} / \mathrm{nm}\left(\varepsilon / \mathrm{M}^{-1} \mathrm{~cm}^{-1}\right)$ & $E_{\mathrm{ox}}^{\mathrm{b}} / \mathrm{V}$ & $E_{0-0}{ }^{\mathrm{c}} / \mathrm{V}$ & $E_{\mathrm{LUMO}} \mathrm{d} / \mathrm{V}$ & $J_{\mathrm{sc}}\left(\mathrm{mA} \mathrm{cm}^{-2}\right)$ & $V_{\mathrm{oc}}(\mathrm{V})$ & $F F$ & $\eta^{\mathrm{e}}(\%)$ \\
\hline $\mathrm{JJ}-12$ & $531(15,430) ; 420(24,430)$ & 0.92 & 1.88 & -0.96 & 16.47 & 0.71 & 0.71 & 8.34 \\
\hline $\mathrm{N} 3$ & $520(14,400) ; 380(14,682)$ & & & & 14.52 & 0.72 & 0.69 & 7.23 \\
\hline
\end{tabular}

${ }^{a}$ Absorption spectra was measured in ethanol solution. ${ }^{\mathrm{b}}$ Oxidation potential of dyes on $\mathrm{TiO}_{2}$ were measured in $\mathrm{CH}_{3} \mathrm{CN}_{\text {with }} 0.1 \mathrm{M}\left(\mathrm{n}-\mathrm{C}_{4} \mathrm{H}_{9}\right)_{4} \mathrm{NPF}_{6}$ with a scan rate of $50 \mathrm{mVs}^{-1}$ (versus NHE). ${ }^{\mathrm{c}} E_{0-0}$ was determined from intersection of absorption and emission spectra in ethanol. ${ }^{\mathrm{d}} E_{\mathrm{LUMO}}$ was calculated by $E_{\mathrm{ox}}-E_{0-0}$. ePerformances of DSSCs were measured with $0.18 \mathrm{~cm}^{2}$ working area. Electrolyte: $0.6 \mathrm{M} \mathrm{DMPII}, 0.05 \mathrm{M} \mathrm{I}_{2}, 0.1 \mathrm{M} \mathrm{LiI}$, and tert-butylpyridine in acetonitrile.

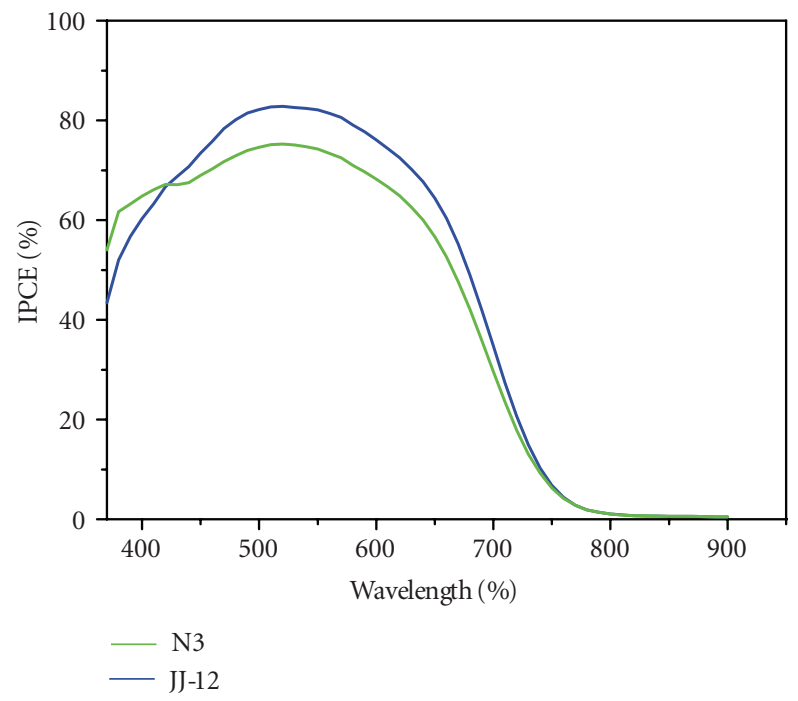

Figure 3: IPCE of JJ-12 (blue line) and N3 (green line).

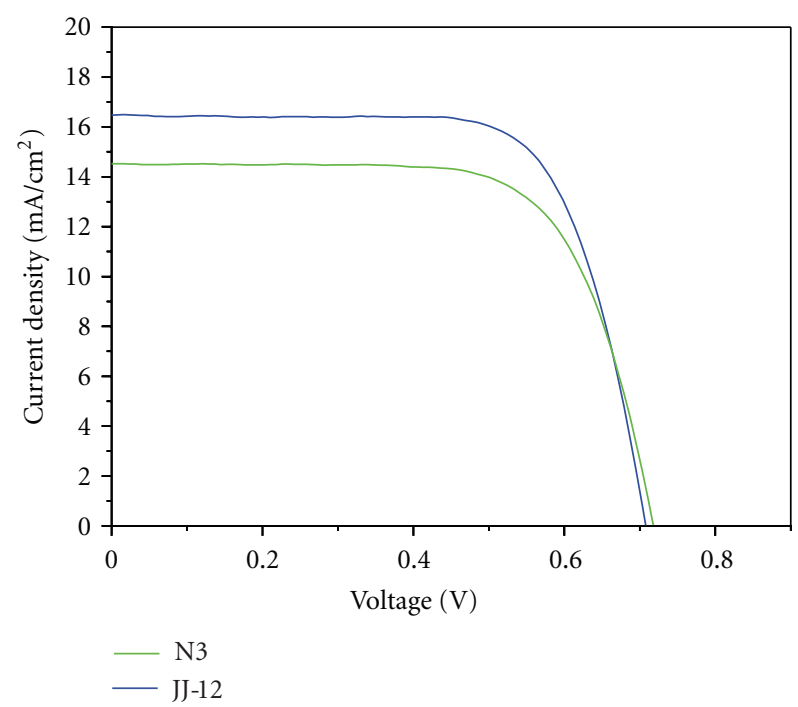

Figure 4: $J$ - $V$ curve of JJ-12 (blue line) and N3 (green line).

same condition. The JJ-12 sensitizer's IPCE spectrum is more enhanced in $420-740 \mathrm{~nm}$ range compared to that of $\mathrm{N} 3$ as a result of extended $\pi$-conjugation of fused triphenylamine ring, which is consistent with the absorption spectrum of JJ12.

The $J-V$ curve for the devices based on $\mathbf{J J}-12$ is shown and compared with that of N3 in Figure 4. Under standard

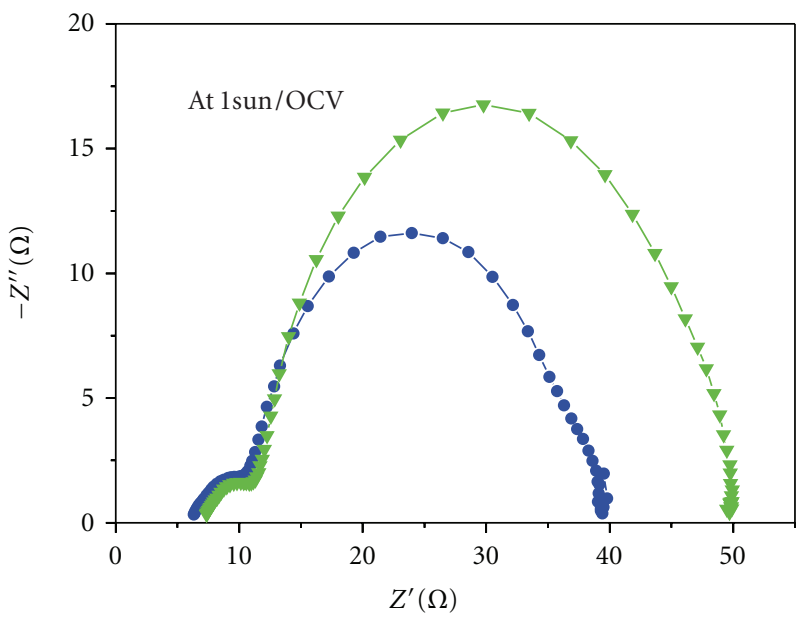

(a)

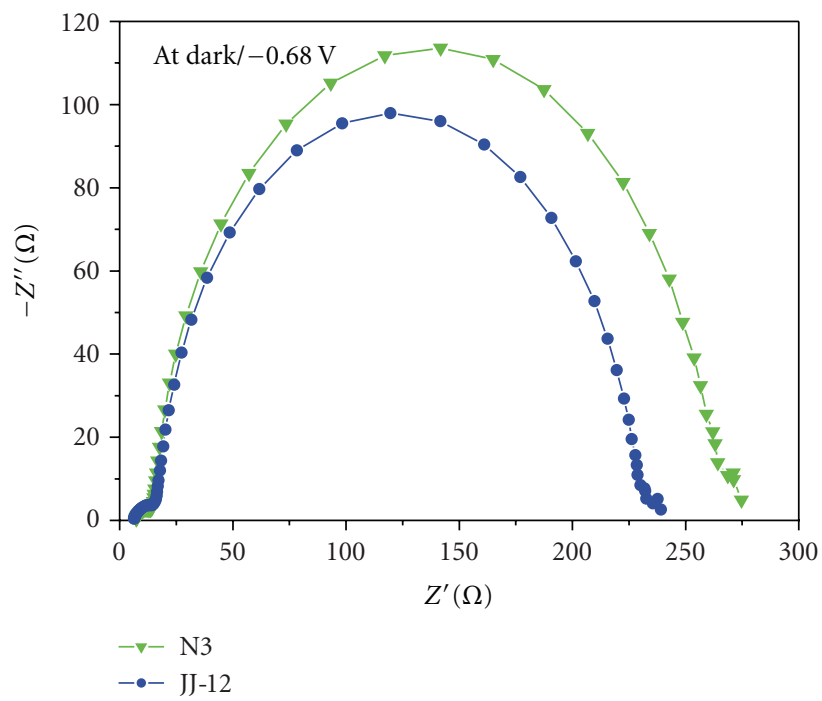

(b)

FIGURE 5: Electrochemical impedance spectra measured under the illumination (1 sun) and in the dark for the cells with different dye adsorption conditions (i.e., JJ-12 (blue), N3 (green)).

global AM1.5 solar condition, the JJ-12 sensitized cell gave a short-circuit photocurrent density $\left(J_{\mathrm{sc}}\right)$ of $16.47 \mathrm{mAcm}^{-2}$, an open-circuit voltage $\left(V_{\text {oc }}\right)$ of $0.71 \mathrm{~V}$, and a fill factor of 0.71 , corresponding to an overall conversion efficiencies $\eta$ of $8.34 \%$. The photovoltaic performance of the $\mathbf{J J}-\mathbf{1 2}$ and N3 sensitized cells is presented in Table 1. Under the same condition, the $\mathrm{N} 3$ sensitized cell gave a $J_{\mathrm{sc}}$ of $14.52 \mathrm{mAcm}^{-2}$, 


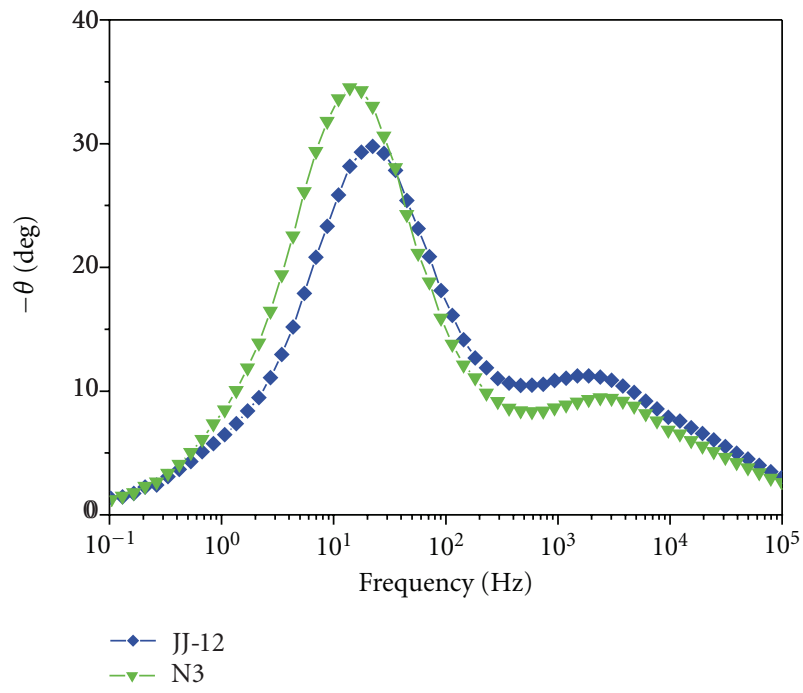

Figure 6: Electrochemical impedance spectra of JJ-12 and N3sensitized cells in the form of a bode phase plot(Measured under open-circuit conditions and AM 1.5 simulated sunlight illumination $\left(100 \mathrm{mWcm}^{-2}\right)$.

$V_{\text {oc }}$ of $0.72 \mathrm{~V}$, and a fill factor of 0.69 , corresponding to $\eta$ of $7.23 \%$.

The ac impedances of the cells were measured under the illumination conditions. Figure 5(a) shows the ac impedance spectra measured under open-circuit conditions and under illumination of $100 \mathrm{mWcm}^{-2}$. The radius of the intermediate-frequency semicircle in the Nyquist plot decreased in the order of $\mathrm{N} 3(34.55 \Omega)>$ JJ-12 $(22.50 \Omega)$, indicating the improved electron generation and transport. This result is in good agreement with that of short-circuit photocurrent trend shown in Table 1. Figure 5(b) shows the ac impedance spectrum measured under dark condition. In the dark under forward bias $(-0.68 \mathrm{~V})$, the semicircle in intermediate frequency regime demonstrates the dark reaction impedance caused by the electron transport from the conduction band of $\mathrm{TiO}_{2}$ to $\mathrm{I}_{3}{ }^{-}$ions in electrolyte. The increased radius of the semicircle in intermediate frequency regime implies a reduced electron recombination rate at the dyed $\mathrm{TiO}_{2}$ /electrolyte interface. In dark, the radius of the intermediate-frequency semicircle showed the increasing order of JJ-12 $(214.70 \Omega)<\mathbf{N} 3(243.90 \Omega)$, in accord with the trends of the $V_{\text {oc }}$ value in Table 1 .

The electron lifetime can be estimated from the following relationship. $\tau_{c}=1 / \omega_{\max }=1 / 2 \pi f_{\max } ; f_{\max }$ is the maximum frequency of the intermediate frequencies peak [34]. The results are displayed in the form of a bode-phase plot, as shown in Figure 6. The $f_{\max }$ values of $\mathbf{J J - 1 2}$ and $\mathbf{N} 3$ are $22.63 \mathrm{~Hz}$ and $13.81 \mathrm{~Hz}$, respectively. The $\tau_{c}$ values show a significant gap among the dyes, resulting in the increasing order of $\mathbf{N} \mathbf{3}>\mathbf{J J}-\mathbf{1 2}$. The different $\tau_{c}$ values might be caused by the different molecular structure of the dyes. The low value of $\tau_{c}$ in $\mathbf{~ J J - 1 2}$ compared to those of $\mathbf{N 3}$ may be due to the defects of the JJ-12 monolayer on the $\mathrm{TiO}_{2}$ electrodes. The results of the electron lifetime are well consistent with those of the $V_{\text {oc }}$ in Table 1.

\section{Conclusions}

In conclusion, a novel ruthenium bipyridyl sensitizer incorporating highly conjugated benzo[1,9] quinolizino(acridin2-yl)vinyl units has been synthesized and characterized. A solar-cell device based on the sensitizer JJ-12 in conjunction with a volatile electrolyte yielded an overall conversion efficiency of $8.34 \%$. The efficient performance of JJ-12 is attributed to its high absorption extinction coefficient of MLCT band and extended absorption in the visible region. We believe that the development of highly efficient ruthenium sensitizers is possible through meticulous molecular engineering.

\section{Acknowledgment}

This work was supported by the Electronics and Telecommunications Research Institute (ETRI).

\section{References}

[1] B. O’Regan and M. Grätzel, "A low-cost, high-efficiency solar cell based on dye-sensitized colloidal $\mathrm{TiO}_{2}$ films," Nature, vol. 353, no. 6346, pp. 737-740, 1991.

[2] K. Hara, H. Sugihara, Y. Tachibana et al., "Dye-sensitized nanocrystalline $\mathrm{TiO}_{2}$ solar cells based on ruthenium(II) phenanthroline complex photosensitizers," Langmuir, vol. 17, no. 19, pp. 5992-5999, 2001.

[3] T. Horiuchi, H. Miura, K. Sumioka, and S. Uchida, "High efficiency of dye-sensitized solar cells based on metal-free indoline dyes," Journal of the American Chemical Society, vol. 126, no. 39, pp. 12218-12219, 2004.

[4] S. A. Haque, S. Handa, K. Peter, E. Palomares, M. Thelakkat, and J. R. Durrant, "Supermolecular control of charge transfer in dye-sensitized nanocrystalline $\mathrm{TiO}_{2}$ films: towards a quantitative structure-function relationship," Angewandte ChemieInternational Edition, vol. 44, no. 35, pp. 5740-5744, 2005.

[5] D. Kuang, P. Walter, F. Nüesch et al., "Co-sensitization of organic dyes for efficient ionic liquid electrolyte-based dyesensitized solar cells," Langmuir, vol. 23, no. 22, pp. 1090610909, 2007.

[6] M. K. Nazeeruddin, F. D. Angelis, S. Fantacci et al., "Combined experimental and DFT-TDDFT computational study of photoelectrochemical cell ruthenium sensitizers," Journal of the American Chemical Society, vol. 127, no. 48, pp. 16835-16847, 2005.

[7] T. Renouard, R. A. Fallahpour, M. K. Nazeeruddin et al., "Novel ruthenium sensitizers containing functionalized hybrid tetradentate ligands: synthesis, characterization, and INDO/S analysis," Inorganic Chemistry, vol. 41, no. 2, pp. 367378, 2002.

[8] M. K. Nazeeruddin, P. Péchy, T. Renouard et al., "Engineering of efficient panchromatic sensitizers for nanocrystalline $\mathrm{TiO}_{2}$ based solar cells," Journal of the American Chemical Society, vol. 123, no. 8, pp. 1613-1624, 2001.

[9] K. Chen, Y. H. Hong, Y. Chi, W. H. Liu, B. S. Chen, and P. T. Chou, "Strategic design and synthesis of novel tridentate bipyridine pyrazolate coupled $\mathrm{Ru}$ (ii) complexes to achieve superior solar conversion efficiency," Journal of Materials Chemistry, vol. 19, no. 30, pp. 5329-5335, 2009. 
[10] K. J. Jiang, N. Masaki, J. B. Xia, S. Noda, and S. Yanagida, "A novel ruthenium sensitizer with a hydrophobic 2-thiophen2-yl-vinyl- conjugated bipyridyl ligand for effective dye sensitized $\mathrm{TiO}_{2}$ solar cells," Chemical Communications, no. 23, pp. 2460-2462, 2006.

[11] C. Y. Chen, S. J. Wu, C. G. Wu, J. G. Chen, and K. C. Ho, "A ruthenium complex with superhigh light-harvesting capacity for dye-sensitized solar cells," Angewandte ChemieInternational Edition, vol. 45, no. 35, pp. 5822-5825, 2006.

[12] C. Y. Chen, S. J. Wu, J. Y. Li, C. G. Wu, J. G. Chen, and K. C. Ho, "A new route to enhance the light-harvesting capability of ruthenium complexes for dye-sensitized solar cells," Advanced Materials, vol. 19, no. 22, pp. 3888-3891, 2007.

[13] Y. Cao, Y. Bai, Q. Yu et al., "Dye-sensitized solar cells with a high absorptivity ruthenium sensitizer featuring a 2-(hexylthio)thiophene conjugated bipyridine," Journal of Physical Chemistry C, vol. 113, no. 15, pp. 6290-6297, 2009.

[14] F. Gao, Y. Wang, D. Shi et al., "Enhance the optical absorptivity of nanocrystalline $\mathrm{TiO}_{2}$ film with high molar extinction coefficient ruthenium sensitizers for high performance dyesensitized solar cells," Journal of the American Chemical Society, vol. 130, no. 32, pp. 10720-10728, 2008.

[15] P. Wang, C. Klein, R. Humphry-Baker, S. M. Zakeeruddin, and M. Grätzel, "A high molar extinction coefficient sensitizer for stable dye-sensitized solar cells," Journal of the American Chemical Society, vol. 127, no. 3, pp. 808-809, 2005.

[16] D. Kuang, C. Klein, S. Ito et al., "High-Efficiency and stable mesoscopic dye-sensitized solar cells based on a high molar extinction coefficient ruthenium sensitizer and nonvolatile electrolyte," Advanced Materials, vol. 19, no. 8, pp. 1133-1137, 2007.

[17] P. Wang, S. M. Zakeeruddin, J. E. Moser et al., "Stable new sensitizer with improved light harvesting for nanocrystalline dye-sensitized solar cells," Advanced Materials, vol. 16, no. 20, pp. 1806-1811, 2004.

[18] P. A. Anderson, G. F. Strouse, J. A. Treadway, F. R. Keene, and T. J. Meyer, "Black MLCT absorbers," Inorganic Chemistry, vol. 33, no. 18, pp. 3863-3864, 1994.

[19] R. J. Bushby, D. R. McGill, K. M. Ng, and N. Taylor, "p-Doped high spin polymers," Journal of Materials Chemistry, vol. 7, no. 12, pp. 2343-2354, 1997.

[20] C. Zhang, A. W. Harper, and L. R. Dalton, "Formylation of diethyl 2-thienylmethylphosphonate for one-pot synthesis of aminothienostilbene-carboxaldehyde," Synthetic Communications, vol. 31, no. 9, pp. 1361-1365, 2001.

[21] C. Lee, J. H. Yum, H. Choi et al., "Phenomenally high molar extinction coefficient sensitizer with "donor-acceptor" ligands for dye-sensitized solar cell applications," Inorganic Chemistry, vol. 47, no. 7, pp. 2267-2273, 2008.

[22] S. R. Jang, C. Lee, H. Choi et al., "Oligophenylenevinylenefunctionalized $\mathrm{Ru}(\mathrm{II})$-bipyridine sensitizers for efficient dyesensitized nanocrystalline $\mathrm{TiO}_{2}$ solar cells," Chemistry of Materials, vol. 18, no. 23, pp. 5604-5608, 2006.

[23] T. Bessho, E. Yoneda, J. H. Yum et al., "New paradigm in molecular engineering of sensitizers for solar cell applications," Journal of the American Chemical Society, vol. 131, no. 16, pp. 5930-5934, 2009.

[24] F. Matar, T. H. Ghaddar, K. Walley, T. DosSantos, J. R. Durrant, and B. O'Regan, "A new ruthenium polypyridyl dye, TG6, whose performance in dye-sensitized solar cells is surprisingly close to that of N719, the 'dye to beat' for 17 years," Journal of Materials Chemistry, vol. 18, no. 36, pp. 4246-4253, 2008.

[25] K. S. Chen, W. H. Liu, Y. H. Wang et al., "New family of ruthenium-dye-sensitized nanocrystalline $\mathrm{TiO}_{2}$ solar cells with a high solar-energy-conversion efficiency," Advanced Functional Materials, vol. 17, no. 15, pp. 2964-2974, 2007.

[26] F. Gao, Y. Wang, J. Zhang et al., "A new heteroleptic ruthenium sensitizer enhances the absorptivity of mesoporous titania film for a high efficiency dye-sensitized solar cell," Chemical Communications, no. 23, pp. 2635-2637, 2008.

[27] M. K. Nazeeruddin, A. Kay, I. Rodicio et al., "Conversion of light to electricity by cis-X2bis(2,2' -bipyridyl$4,4^{\prime}$-dicarboxylate)ruthenium(II) charge-transfer sensitizers $\left(\mathrm{X}=\mathrm{Cl}^{-}, \mathrm{Br}^{-}, \mathrm{I}^{-}, \mathrm{CN}^{-}\right.$, and $\left.\mathrm{SCN}^{-}\right)$on nanocrystalline $\mathrm{TiO}_{2}$ electrodes," Journal of the American Chemical Society, vol. 115, no. 14, pp. 6382-6390, 1993.

[28] X. Li, K. Hou, X. Duan, F. Li, and C. Huang, "Ruthenium(II) complex based on 4,4'-di( $p$-methylphenyl)-2,2' - bipyridine: synthesis and photoelectrochemical properties," Inorganic Chemistry Communications, vol. 9, no. 4, pp. 394-396, 2006.

[29] A. M. Bond, G. B. Deacon, J. Howitt, D. R. MacFarlane, L. Spiccia, and G. Wolfbauer, "Voltammetric determination of the reversible redox potential for the oxidation of the highly surface active polypyridyl ruthenium photovoltaic sensitizer cis-Ru(II)(dcbpy $)_{2}(\mathrm{NCS})_{2}$," Journal of the Electrochemical Society, vol. 146, no. 2, pp. 648-656, 1999.

[30] P. Wang, S. M. Zakeeruddin, J. E. Moser, and M. Grätzel, “A new ionic liquid electrolyte enhances the conversion efficiency of dye-sensitized solar cells," Journal of Physical Chemistry B, vol. 107, no. 48, pp. 13280-13285, 2003.

[31] C. Y. Chen, J. G. Chen, S. J. Wu, J. Y. Li, C. G. Wu, and K. C. Ho, "Multifunctionalized ruthenium-based supersensitizers for highly efficient dye-sensitized solar cells," Angewandte Chemie-International Edition, vol. 47, no. 38, pp. 7342-7345, 2008.

[32] A. Islam, F. A. Chowdhury, Y. Chiba et al., "Synthesis and characterization of new efficient tricarboxyterpyridyl ( $\beta$ diketonato) ruthenium(II) sensitizers and their applications in dye-sensitized solar cells," Chemistry of Materials, vol. 18, no. 22, pp. 5178-5185, 2006.

[33] D. Kuang, C. Klein, S. Ito et al., "High molar extinction coefficient ion-coordinating ruthenium sensitizer for efficient and stable mesoscopic dye-sensitized solar cells," Advanced Functional Materials, vol. 17, no. 1, pp. 154-160, 2007.

[34] R. Kern, R. Sastrawan, J. Ferber, R. Stangl, and J. Luther, "Modeling and interpretation of electrical impedance spectra of dye solar cells operated under open-circuit conditions," Electrochimica Acta, vol. 47, no. 26, pp. 4213-4225, 2002. 


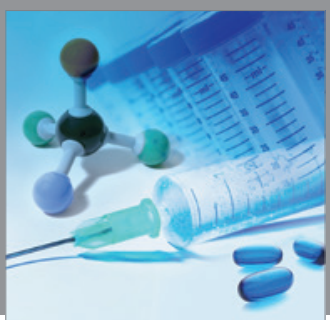

International Journal of

Medicinal Chemistry

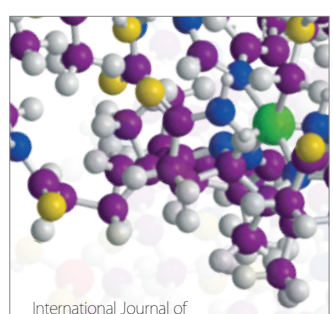

Carbohydrate Chemistry

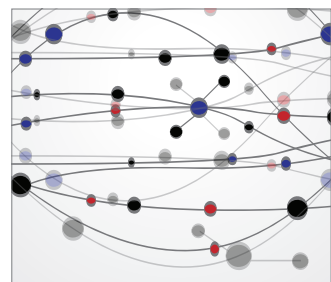

The Scientific World Journal
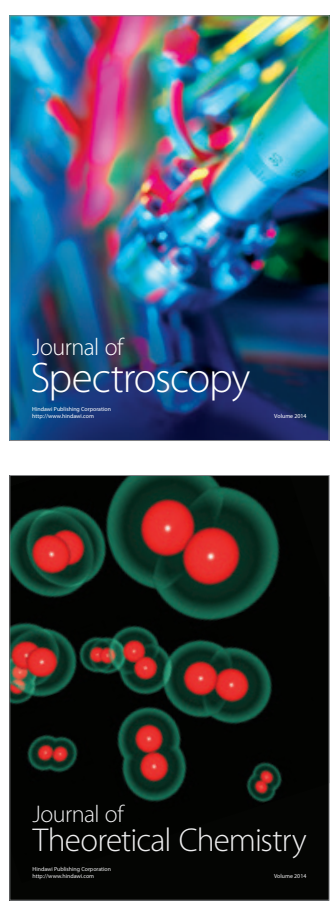
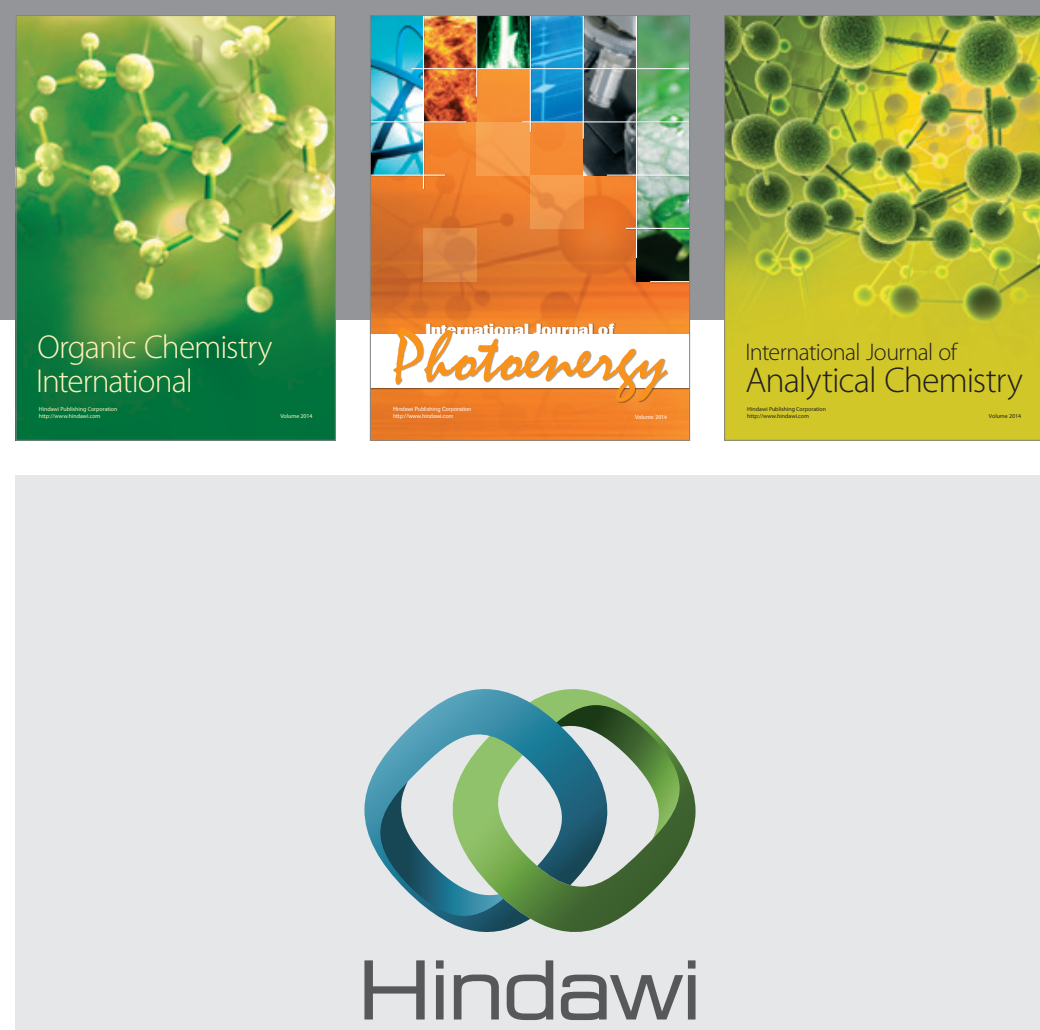

Submit your manuscripts at

http://www.hindawi.com
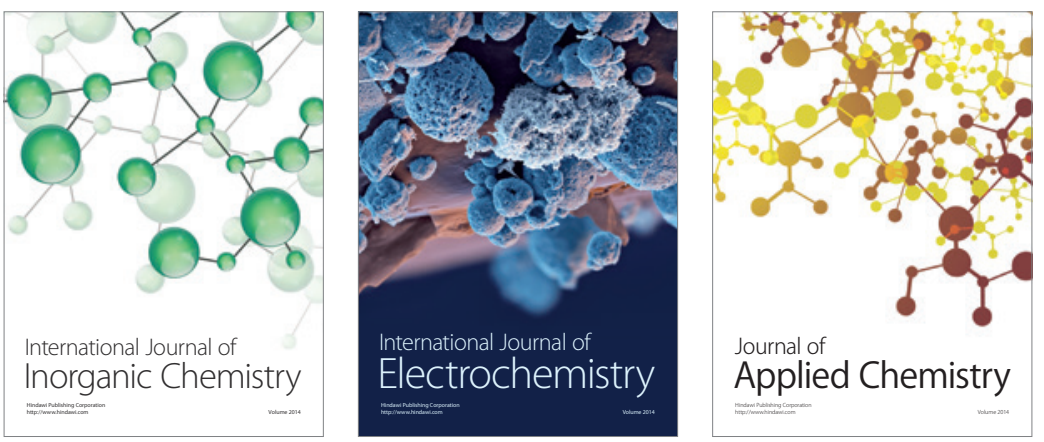

Journal of

Applied Chemistry
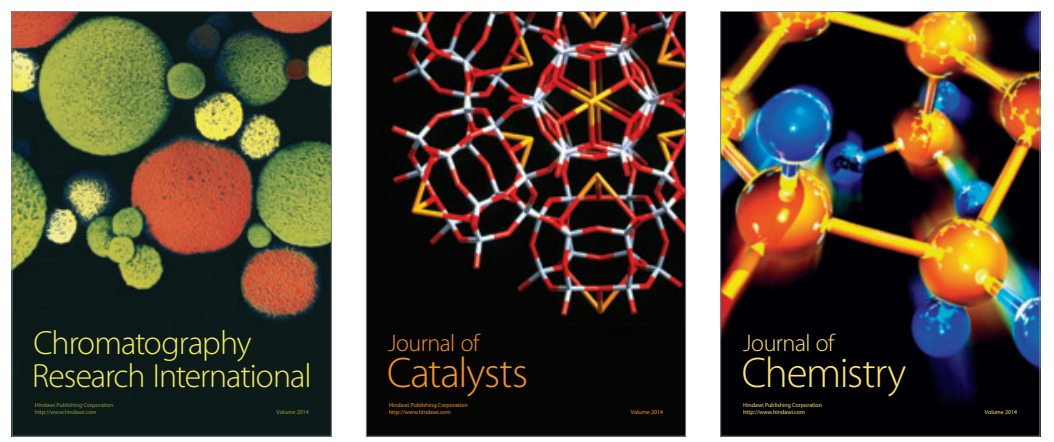
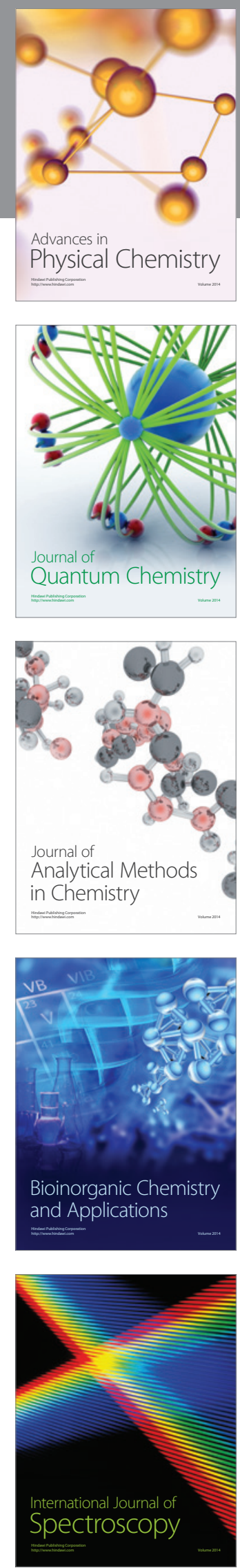